\title{
Atlantis
}

Critical Studies in Gender, Culture \& Social Justice

Études critiques sur le genre, la culture, et la justice

\section{Speaking Freely vs. Dignitary Harm: Balancing Students' Freedom of Expression and Associational Rights with their Right to an Equitable Learning Environment}

\section{Elizabeth Brulé}

Volume 41, Number 1, 2020

URI: https://id.erudit.org/iderudit/1074013ar

DOI: https://doi.org/10.7202/1074013ar

See table of contents

Publisher(s)

Mount Saint Vincent University

ISSN

1715-0698 (digital)

Explore this journal

Cite this article

Brulé, E. (2020). Speaking Freely vs. Dignitary Harm: Balancing Students' Freedom of Expression and Associational Rights with their Right to an Equitable Learning Environment. Atlantis, 41(1), 21-33.

https://doi.org/10.7202/1074013ar

\section{Article abstract}

In this article, I examine the difficulty of using student codes of conduct and civility policies as a way to restrict harmful speech. I argue that policies used to monitor students' non-academic behaviour provide administrators with a means to restrict and surveil students' political advocacy work, especially marginalized students' advocacy. Rather than providing a 'safe' learning environment, codes of conduct curtail students' opportunities for freedom of expression and limits their ability for critical pedagogical engagement with controversial ideas. Drawing on case studies at Canadian universities, I illustrate the contradictory challenges that student activists encounter when attempting to balance principles of freedom of expression and principles of equity on university campuses. Rather than use codes of conduct, I argue that administrators should adopt criteria that help students identify and limit dignitary harms. In doing so, students will be better equipped to assess their expressive freedom and associational rights with the rights of others to an equitable learning environment. Moreover, such an approach represents a decolonial shift and promises to expand our narrow liberal conception of rights and ensure marginalized peoples' voices and worldviews are heard.
All Rights Reserved @ Elizabeth Brulé, 2020

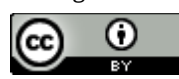

This document is protected by copyright law. Use of the services of Érudit (including reproduction) is subject to its terms and conditions, which can be viewed online. 


\section{Speaking Freely vs. Dignitary Harm: Balancing Students' Freedom of Expression and Associational Rights with their Right to an Equitable Learning Environment}

Elizabeth Brulé is an Assistant Professor in the Department of Gender Studies, at Queen's University, with a research focus in institutional ethnography, Indigenous feminist, anti-racist and anti-colonialist theory and activism. She is of Franco-Ontarian and Métis ancestry.

Abstract: In this article, I examine the difficulty of using student codes of conduct and civility policies as a way to restrict harmful speech. I argue that policies used to monitor students' non-academic behaviour provide administrators with a means to restrict and surveil students' political advocacy work, especially marginalized students' advocacy. Rather than providing a 'safe' learning environment, codes of conduct curtail students' opportunities for freedom of expression and limits their ability for critical pedagogical engagement with controversial ideas. Drawing on case studies at Canadian universities, I illustrate the contradictory challenges that student activists encounter when attempting to balance principles of freedom of expression and principles of equity on university campuses. Rather than use codes of conduct, I argue that administrators should adopt criteria that help students identify and limit dignitary harms. In doing so, students will be better equipped to assess their expressive freedom and associational rights with the rights of others to an equitable learning environment. Moreover, such an approach represents a decolonial shift and promises to expand our narrow liberal conception of rights and ensure marginalized peoples' voices and worldviews are heard.

Keywords: codes of conduct, equitable learning environments, freedom of expression, harmful speech
Tpholding both liberal principles of freedom of expression and the principles of equity as protected respectively in the Canadian Charter of Rights and Freedoms and Canadian Human Rights legislation presents real political challenges. With the rise in extreme right groups that espouse white nationalism on campuses in the last decade, the desire to create a safe learning environment for all students and, in particular, for marginalized students, has resulted in concerns about whether the speech of the former and their associational rights should be increasingly regulated (Masri 2011; Moon 2014; Palfrey 2017; Spencer, Tyahur, \& Jackson 2016; Waldron 2012). Still, others argue that students' rights to free speech and associational rights should have the same status on university campuses as they would off campus (Cameron 2014; CAUT 2018, 2019; Chemerinsky \& Gillman 2017; Cloud 2015). They contend that restrictions on academic freedom and freedom of expression through student codes of conduct and civility policies are problematic. While acknowledging the undeniable harms of hate speech, they nonetheless counter that the risk of censoring legitimate political speech outweighs such harms.

In this article, I examine the current debate around the use of student codes of conduct and civility policies to restrict harmful speech and their effects on marginalized students' political advocacy work on $\mathrm{Ca}$ nadian campuses. I argue that the use of codes of conduct and civility policies for non-academic behaviour to monitor students within the Canadian post-secondary system provides administrators with a means to restrict and, indeed, surveil students' political advocacy work, especially marginalized students' advocacy. Rather than providing a 'safe' learning environment, such policies and codes of conduct cur- 
tail these students' opportunities for freedom of expression and limits their ability for critical pedagogical engagement with controversial ideas. Moreover, such restrictions have provided the impetus for conservative provincial governments such as Alberta's United Conservative Party and Ontario's Conservative Party to compel universities to adopt free speech policies. While seeming to uphold students' Charter rights, such directives also require that student conduct rules be in place to penalize groups that 'disrupt' (or rather, counter-protest) the free speech of others. In this article, I draw upon case studies at Canadian universities to illustrate the contradictory and often precarious challenges that student activists encounter when attempting to balance principles of freedom of expression and principles of equity on university campuses, and how administrators apply student codes of conduct in often discriminatory ways. While universities are exempt from upholding Charter rights due to institutional self-governance and academic freedom, I contend that administrators should move away from student codes of conduct and civility policies and, instead, adopt criteria that helps students identify and limit dignitary harms whilst balancing their right to associational and expressive freedoms. In developing such criteria, students will be better equipped to assess their expressive freedom and associational rights with the rights of others to an equitable learning environment. Moreover, such an endeavour may help foster students' sense of collective responsibility in upholding dignitary rights on campuses and encourage critical consciousness. ${ }^{1}$

\section{Hate Speech in Ontario Universities}

In the past decade, there has been an increasing number of reports of racist propaganda at Ontario universities. Steven Zhou reported in Academic Matters that:

In the fall of 2015, "White Student Union" posters were found at Ryerson University, York University, and the University of Toronto's St. George Campus. A year later, flyers decrying "anti-white racism" were found on the McMaster University campus in Hamilton, while a study room in McMaster's Innis Library was booked with the note: "McMaster KKK meet- ing." And at Western University, some students posed in front of a giant \#WesternLivesMatter banner. $(2017,1)$

More recently, in the fall semester of 2019 at Queen's University, a racist, homophobic note that threatened violence against its student residents was posted in Queen's University's Chown Hall residence common room. A day prior, a Métis and an 2S-LGBTQ+ flag was stolen from the same fourth-floor room-a floor designated for Indigenous students and their allies. As a social justice advocate of Franco-Ontarian and Métis heritage, and a gender studies faculty member, I was concerned for my students' safety and the impact that such violence would have on them and their families. I was not alone. From the university's principal, Patrick Deane, to a majority of students, staff, and faculty, the reaction was one of shock and disgust (CBC News 2019). Over 1,000 students, staff, and faculty along with the broader Kingston community took to the streets to protest the hateful note and to support our Indigenous and 2S-LGBTQ+ students. Organized by Four Directions Indigenous Student Centre, the march called on all members of the Queen's community to stand up against racism, homophobia, and transphobia on campus. Flags representing the Haudenosaunee Confederacy, the Métis Nation, the Pride flag, the Trans Pride flag, and the Two Row Wampum were hung outside Four Directions in support of our Indigenous and 2S-LGBTQ+ students, only to be vandalized the last day of Pride Month in June of 2020. A month later, on July 29th, staff discovered damage to the Four Directions' Tipi.

Unfortunately, such hate speech acts are not uncommon at Queen's. Prior to the Chown Hall incident, in September of 2019, buildings, a sidewalk, and an Indigenous banner were covered in racist and antiSemitic graffiti (Svonkin 2019). And in 2016, Queen's students held an off-campus Halloween party that became infamous for its racist costume attire as reported in major news outlets across the country (Journal Editorial Board 2020). While the Queen's administration has taken such acts quite seriously, calling in local police to investigate and publicly denouncing these hateful speech acts, we are nonetheless left with the question: How can the university community foster a 
more inclusive campus environment, free from discrimination and hateful speech, while at the same time ensuring the expressive and associational rights of its student population?

\section{A Devolution of Students' Rights Under the Provincial Ontario Conservative Govern- ment's Free Speech Directive}

Up until recently, a post-secondary student's constitutional rights to freedom of expression and the right to assembly have not been protected. ${ }^{2}$ In Canada, legal statutes and legislative acts have maintained a university's autonomy vis-a-vis the state and its right to set its own rules and regulations regarding students' academic and non-academic conduct in fulfilling its educational mission (Cameron 2014; Moon 2014, 2018; Stewart 2010). As Richard Moon notes: "Since the university is not (as a general matter) a government actor, subject to the Canadian Charter of Rights and Freedoms, this is significantly a political or institutional question about the kinds of speech that advance the university's educational mission or are consistent with its operation" $(2014,185)$. In upholding notions of institutional self-governance and academic freedom, administrators further define the codes of conduct that students within the institution must abide by (Brulé 2015). They also determine the disciplinary procedures and processes that dissenters are subjected to; speech codes, codes of conduct, restrictions on use of space, disciplinary tribunals, appeal processes and the like all come under university administrators' jurisdiction (Brulé 2015). While universities are exempt from upholding a student's Charter rights, they have nonetheless purported to support a student's expressive and associational rights, albeit on a limited case by case basis (Brulé 2015).

Since the 1960s, university administrators have had to grapple with how to address questions of freedom of expression and equity. Prior to this time, in loco parentis (in place of the parent) rules were used to regulate all aspects of a student's life on campus (Brulé 2015, 2020). With the rise of the left counterculture and the Free Speech Movement (FSM) of the 1960s, students challenged the paternalistic rules of in loco parentis (Post 2002). Student codes of conduct have since re- placed these rules and evolved to "resemble a quasi-judicial framework that is used to monitor, discipline and control political dissent on campuses" within a corporatized university context (Brulé 2015, 161).

In recent years, such policies on non-academic behaviour have been meet with accusations of 'political correctness' and a stifling of free speech by right-wing extremists and the far right in order to discredit human rights and social justice advocates. The abuse of free speech as a regulatory discourse by the conservative far right, while reminiscent of the 'cultural war' of the 1980s, is again evident in recent provincial government directives to post-secondary institutions. Last year, the conservative governments of both Alberta and Ontario instituted new free speech directives for colleges and universities. Modelled after the Chicago Principles of Free Expression developed at the University of Chicago in 2014, the Ontario Ford government introduced a new directive in August of 2018 requiring colleges and universities to develop a freedom of speech policy by January 1, 2019. The directive states that:

- The universities/colleges should not attempt to shield students from ideas or opinions that they disagree with or find offensive;

- While members of the university/college are free to criticize and contest views expressed on campus, they may not obstruct or interfere with the freedom of others to express their views;

- Speech that violates the law is not allowed. (Ontario, Office of the Premier, August 30, 2018, 1)

The Ford government's directive also compels universities and colleges to use their existing student disciplinary measures to punish students "whose actions are contrary to the policy" (Ontario, Office of the Premier, August 30, 2018, 1). For instance, any "ongoing disruptive protesting that significantly interferes with the ability of an event to proceed" should be considered grounds for disciplinary action by university and college administrators (Ontario, Office of the Premier, August 30, 2018, 1). Such a requirement obliges administrators to discipline students who peacefully contest the presence of public speakers they find offensive. Moreover, in order to receive institutional 
funding, student unions and clubs must comply with the Ford government's 'free speech' requirement. The directive further compels administrators "to use their existing mechanisms to handle complaints and ensure compliance" (Ontario, Office of the Premier, August $30,2018,1)$.

Of further significance is the use of the Higher Education Quality Council of Ontario (HEQCO) to monitor conformity with the new directive. The government's news release states:

If institutions fail to comply with government requirements to introduce and report on free speech policies, or if they fail to follow their own policies once implemented, the Ministry may respond with reductions to their operating grant funding, proportional to the severity of non-compliance. (Ontario, Office of the Premier, August 30, 2018, 2)

Seemingly in line with freedom of expression policies already in place in most colleges and post-secondary institutions, critics contend that these types of free speech directives represent an effort to normalize right-wing extremist discourse on campuses (BenPorath 2018; Cohn 2019; James 2018; Rangwala 2019; Zachariah 2019). Moreover, such free speech policies have not been evenly upheld within the collegium. For instance, marginalized students have been disproportionally subjected to campus regulatory and quasi-judicial policies and procedures, which has resulted in restricting rather than increasing their ability to express political views on campus (Brulé 2015; Carey 2016; Nadeau \& Sears 2011; Smeltzer \& Hearn 2015; Stewart 2010; Turk 2014, 2017; Turk \& Manson 2017).

\section{The Uneven Application of Student Codes of Conduct Policies for Non-academic Stu- dent Behaviour}

The disjuncture that marginalized students experience between their expressive freedom and associational rights within the quasi-juridical framework of codes of conduct are contradictory, with few institutional processes in place to protect students from discriminatory or unfair practices (Brulé 2015; Nadeau \& Sears 2011; Smeltzer \& Hearn 2015; Stewart 2010). Such was the case at Dalhousie University in Halifax, Nova Scotia in 2017 when student leader and social justice activist Masuma Khan was charged under the university's student code of conduct for having posted an 'offending' Facebook post in the summer of that year. As vicepresident academic external of the student union, Khan had tabled a motion to opt out of Canada's celebration activities of its 150th anniversary of Confederation, arguing that such activities were an act of ongoing colonization (Rahr 2017). Young Progressive Conservative students denounced the policy on the Student Union's Facebook page, which prompted Khan's comment, "White fragility can kiss my ass" (Rahr 2017, 1).

It was this comment that compelled Progressive Conservative member and graduate student Michael Smith to submit a formal complaint against Khan and write an opinion piece condemning her comments in the National Post (Rahr 2017). Khan was subsequently brought forward for violations to the student code of conduct policy for behaviour that could be "reasonably understood as demeaning and intimidating" (Chiose $2017,1)$. While the disciplinary action against her was eventually dropped due to the overwhelming support from staff, students, and faculty for her right to political speech, she was nonetheless subjected to violent threats and hate speech following the student conduct charges (Rahr 2017). In this case, political speech used to contest Canadian colonial institutional practices had been considered "demeaning and intimidating" by university administrators.

Yet, months later, at Ontario's Wilfrid Laurier campus, a debate about the legitimacy of using gender-neutral pronouns was considered a matter of freedom of expression. Graduate student Lindsay Shepherd, who leaked a secretly recorded tape of a meeting convened by her professor for having shown an episode of a TVOntario current affairs program, The Agenda, to her tutorial class, called foul play when challenged for her potentially transphobic behaviour. The Agenda had featured controversial University of Toronto psychology professor Jordan Peterson in a debate on his objection to the use of gender-neutral pronouns. Shepherd aired a five-minute clip of the debate in her tutorial lesson on grammar, which introduced a very controversial 
topic, especially in the wake of Bill C-16 of the Canadian Human Rights Act (2017), prohibiting discrimination against non-gender conforming individuals (Chaudhury 2017). As a teaching assistant, Shepherd was required to deliver the curriculum outlined by the professor of the course. In this instance, the course focused on "basic writing skills including grammar, punctuation, essay formatting and annotated bibliographies" (Chaudhury 2017, 1). As Chaudhury points out, the problem was not that the video was shown, but rather Shepherd's invitation for students to critique whether or not alternative gender pronouns were acceptable when addressing trans and nonbinary people. Such an invitation not only deviated considerably from the course curriculum, but provided a forum for some students to ridicule trans and nonbinary individuals, diminishing their social standing within the classroom and the collegial environment in general and, as such, calling into question their human dignity. ${ }^{3}$ While students do not have academic freedom, they are the beneficiaries of their professor's academic freedom within the classroom. In this case Shepherd had not adhered to the curriculum and was in potential violation of Bill C-16 of the Canadian Human Rights Act (2017).

The public controversy arose when Shepherd released the clandestine recording to the media, proclaiming that her right to free speech and academic freedom had been violated. The content of the recording sparked outrage on the part of the alt-right, which proclaimed that a culture of 'political correctness' was prohibiting open and free debate on campus. Christie Blatchford, journalist and right-wing pundit, argued that Shepherd's free speech was under attack from "leftist authoritarian ideologues" (2017). Wilfrid Laurier's president and vice chancellor, Deborah MacLatchy, defended Shepherd's right to freedom of expression within her tutorials, ${ }^{4}$ despite the professor's objections and protests by 2S-LGBTQ+ students and allies who felt that their right to a safe learning environment had been violated (Chaudhury 2017; Murrel 2017).

Shepherd took matters even further. In the midst of the controversy, she co-founded the Laurier Society for Open Inquiry (LSOI) and invited Faith Goldy, a former Rebel Media journalist and a confirmed white nationalist and white supremacist advocate, to speak on free speech on campus (Chaudhury 2017; Murrel 2017). In response, Laurier's student Rainbow Group, along with gender non-conforming and supportive allies across campus, held a silent counter-protest (Chaudhury 2017). The event was eventually cancelled due to a pulled fire alarm, but not before Goldy and her supporters engaged in a physical altercation with the counter-protesters outside the university complex (Chaudhury 2017; Murrel 2017). After the protest, many members of this marginalized community reported receiving threats, harassment, and online trolling and became victims of doxing 5 (Chaudhury 2017). Greg Bird, an assistant professor at Laurier, gathered over 450 faculty signatures demanding that the president denounce the resulting transphobic actions and develop measures to protect staff and students from such attacks (Bird 2017). Bird argued that the university did not address nor defend the rights of trans people to an equitable learning environment (Lam 2017). He posited that, by not speaking out on behalf of marginalized faculty, staff and students, the president further validated the discriminatory behaviour of the alt-right perpetrators (Bird 2017). In this case, trans students, staff and faculty's right to be shielded from dignity harms within their learning environment was not upheld.

\section{The Aftermath of Ford's Free Speech Direc- tives}

The Ford government's free speech directives have done little to resolve the issue of balancing principles of freedom of expression and principles of equity on Ontario's post-secondary campuses. In fact, as the incidents at Queen's University cited earlier indicate, fascist and far-right groups have been further emboldened to spread hateful speech since the directive was announced. At York University, similar events have taken place. On November 20, 2019, York was the site of a violent confrontation between Students Against Israeli Apartheid (SAIA) and Israeli Zionists at an event sponsored by the student group Herut Canada. Undergraduate student Lauren Isaacs, Herut's president at York, invited Israeli Defence Forces (IDF) reservists to speak on campus. 
The event, which was sanctioned by the university's administration and approved by the Temporary Use of University Space (TUUS) staff and security risk management assessment personnel (York University 2019a), resulted in an unsanctioned "alternative security" presence by the Jewish Defence League (JDL) of Canada-a Jewish religious political organization that has been classified as a right-wing terrorist group by the FBI in the United States (Federal Bureau of Investigation 2001). While both student groups engaged in verbal and physical altercations during the event, university video footage shows individuals bearing the JDL crest assaulting SAIA members (Cromwell 2020, 14). Following the event, Lauren Isaacs thanked the Jewish motorcycle groups (Riders of the Covenant and The Deplorables) and Jewish Defence League for providing security "to help us stay safe" on the Herut's Facebook page (cited in Cromwell 2020 18). Lauren Isaacs' post states:

I personally appointed a security organizer who rallied many people in the community to come out and help us stay safe. He had connections to certain Jewish motorcycle groups like The Riders of the Covenant and The Deplorables, whose members came out and selflessly protected our community. Thank you guys! My security organizer also reached out to the JDL, who sent out a group of guys. We are very grateful to them as they helped keep the protesters away from our event, protected the Jewish students and Zionist community members, and helped to safely escort us home after the event. (cited in Cromwell 2020, 18)

York administrators subsequently banned Meir Weinstein, the head of Jewish Defence League of Canada, on March 2, 2020, under the trespass laws and removal from all three of its campuses, and they are now pursuing damages following the event (Canadian Jewish News 2020). In an e-mail to the Canadian Jewish News (CJN), acting chief spokesperson for the university Yanni Dagonas stated:

It is the right of all York community members to express their views within the law and without fear of intimidation or harassment. As such, external groups with the intent to cause potential disruption are not welcome on university property. York reserves the right to issue trespass notices to anyone with similar intent. (Canadian Jewish News 2020, 2)

On December 3, 2019, the Vice-President, Finance \& Administration and Vice-Provost, Students formally suspended both Herut and SAIA student groups' privileges. And on December 10, 2019 they announced the commissioning of a comprehensive independent external review that was to be conducted by the Honorable Justice Thomas Cromwell, former Justice of the Supreme Court of Canada (York University 2019b).

Justice Cromwell's external Independent Review, released June 2020, provides a comprehensive overview of York's TUUS policy and the security measures put into place and also the findings from his interviews with 22 student groups as well as individuals who participated in the event of November 20. In line with my own empirical research (Brulé 2015), the 85-page report reveals a fundamental lack of transparency in how administrators decide which student events are permitted to take place on campus and which are not (Cromwell 2020). Cromwell also found many of York's policies and procedures on racism, discrimination, and harassment to be in need of clarification for students. Many of the students he interviewed were unsure as to what constituted hate speech and harassment and what the university's responsibility and authority was in relation to student groups (Cromwell 2020, 16). In his report, he further posits that when freedom of expression and equity issues collide, freedom of expression should take precedence (Cromwell 2020). Justice Cromwell also counsels administrators to adopt a more robust security decision-making process for student events and suggests that they consider training special constables vested with the authority to arrest students that do not comply with student conduct rules. Last, he advises that York adopt the International Holocaust Remembrance Alliance (IHRA) definition of anti-Semitism (Cromwell 2020), a highly controversial definition that has been criticized as conflating anti-Semitism with legitimate political critic of Zionism and Israeli government policies (Sachs 2019).

While I concur with Cromwell's recommendation that York clarify the criteria used to determine how permis- 
sion is granted to use university space and define more clearly what constitutes racism, hate speech, discrimination, and harassment, I take issue with his overvaluation of freedom of expression, adoption of the IHRA definition of anti-Semitism and his law and order approach to monitoring approved events. Such recommendations do not only discourage students from critically engaging with controversial political issues (Brulé 2015), but also contributes to the over-policing of marginalized people in Toronto, especially Black people who, according to an Ontario Human Rights Commission report (2018), are 20 times more likely to be the victims of police brutality than White people. As such, I argue that administrators should move away from punitive codes of conduct and civility policies and, instead, assess the potential dignitary harms of a student event in an effort to balance students' expressive freedom with their right to an equitable learning environment. Moreover, I believe that such an approach would help students identify their collective responsibility in balancing these principles. What follows is an overview of Canada's legislative restrictions on hateful speech, how they relate to dignitary harms, and how administrators and students alike might develop criteria with which to assess students' collective responsibility in ensuring that both principles of freedom of expression and principles of equity are upheld on our campuses.

\section{Canadian Hate Speech Laws and the Harm to One's Dignity}

In Canada, few legal restrictions exist to curb free speech: content restrictions on hate speech, defamation, and obscenity laws and false advertising are but a few, as are limits on speech that is considered intimidating or threatening (Moon, 2014, 185). While there are few restrictions on speech, the Criminal Code (1985) does prohibit hate speech that "incites hatred against any identifiable group where such incitement is likely to lead to a breach of the peace" (Criminal Code of Canada (1985), Section 319(1)). The Criminal Code further stipulates that:

$[E]$ veryone who, by communicating statements, other than in private conversation, willfully promotes hatred against any identifiable group is guilty of an indictable offence and is liable to imprisonment for a term not exceeding two years; or an offence punishable on summary conviction. (Criminal Code of Canada (1985), Section 319(2)(a)(b))

The Criminal Code (1985) also includes any speech act that advocates or promotes genocide of any identifiable group by either: "(a) killing members of the group; or (b) deliberately inflicting on the group conditions of life calculated to bring about its physical destruction" (Criminal Code of Canada (1985), Section $318(2)$ ). Within this context, an identifiable group is defined as "any section of the public distinguished by colour, race, religion, national or ethnic origin, age, sex, sexual orientation, gender identity or expression or mental or physical disability" (Criminal Code of Canada (1985), Section 318(4)).

Despite the fact that Canadian hate speech laws were enacted over two decades ago, students are often confused as to what constitutes hate speech. This is particularly evident with student groups' concerns with racist, homophobic, transphobic, ableist, anti-Semitic, and Islamophobic views expressed by extreme right speakers on campuses in the province of Ontario. As illustrated earlier, conservative critics proffer the myth that these student groups are advocates and practitioners of 'political correctness' who are 'too emotional' and 'unable to take political criticism.' However, such fictions mischaracterize the problem of hate speech. Rather than a problem with ideas resulting in "hurt feelings," hate speech is dealing with what Jeremy Waldron characterizes as enduring "artifacts of hateful expression" $(2012,38)$. He states:

The issue is publication and the harm done to individuals and groups through the disfiguring of our social environment by visible, public, and semi-permanent announcements to the effect that in the opinion of one group in the community, perhaps the majority, members of another group are not worthy of equal citizenship. (Waldron 2012, 39)

Within a pluralistic society, with people of varying races, ethnicities, cultures, abilities, gender identities, and sexual orientations, there is a certain expectation that they can live alongside each other free from viol- 
ence, discrimination, or exclusion by others (Waldron 2012). Waldron identifies this space as a public good that contributes to sustaining a good society. For Waldron, hate speech undermines this public good. For vulnerable and marginalized communities that have been subjected to hate speech, a good society provides assurances that they can live as its equal members. Waldron states:

[T]hey, too, are members of society in good standing; they have what it takes to interact on a straightforward basis with others around here, in public, on the streets, in the shops in business, and to be treated-along with everyone else -as proper objects of society's protection and concern. $(2012,5)$

This basic social standing he calls their dignity. He goes on to define hate speech as "both a calculated affront to the dignity of vulnerable members of society and a calculated assault on the public good of inclusiveness" (2012, 5-6).

Waldron sets out to make the distinction between undermining a person's dignity and causing offence. For Waldron, hate speech undermines one's dignity and the public good by calling into question a groups' right to be treated as an equal in their everyday lives (2012 39). That is, when a speaker portrays a particular group as less valuable, less deserving or less than equal, they are causing dignitary harms (Waldron 2012, 39). The purpose and thrust of restricting hate speech is to ensure that one's dignity is protected from attack, "especially against group-directed attacks which claim that all members of a given group are, by virtue of their race or some other characteristic, not worthy of being treated as equal members of society" (Waldron 2012, 39). For Waldron, this type of harm necessitates legal regulation similar to the ways in which personal libel or defamation are regulated (Waldron 2012, 40).

Within Canadian jurisprudence, there has been little consensus about what kinds of behaviours diminish a group's dignity and, as a result, the Supreme Court of Canada has determined that it is no longer useful as a referent in its equality jurisprudence (Schneiderman 2014, 224). Consequently, arguments about the maintenance of group dignity unfortunately do not factor into criminal proceedings involving hate crimes in Canada. This said, several legal scholars use group dignity to argue that there is a need for policies that protects a student's fundamental right to learn and participate in the collegium free from the exigencies of discrimination and harmful speech (Ben-Porath 2017; Masri 2011; Moon 2014; Palfrey 2017; Spencer, Tyahur, \& Jackson 2016; Waldron 2012). Richard Moon argues that certain types of hateful speech, such as racist, sexist, and homophobic speech, are inconsistent with an institution's educational mission and, as such, merit restriction $(2014,186)$. He states that, while:

[r]acial generalizations and insults may not breach the criminal ban on hate speech...when they occur in the workplace or in schools they may be considered unlawful harassment or discrimination under anti-discrimination laws.... The objection to sexist or racist speech on campus is not simply that it is irrational, sometimes vitriolic, and unlikely to contribute to thoughtful discourse; it is also that this speech seeks to undermine the standing of members of a community dedicated to learning and scholarship. (2018 3-4)

Scholars such as Sigal Ben-Porath (2017) agree. She posits that what is needed to ensure both expressive rights and the right to dignity is what she terms "inclusive freedom" within the collegium (2017). She asserts that "inclusive freedom demands that speech on campus be protected as broadly as possible while aiming to ensure that all members of the campus community are recognized-and know that they are recognized-as members in good standing" (2017, 56). Nevertheless, Ben-Porath does not support a restriction on speech based on identity and group affiliation, but rather encourages administrators to "fulfill their civic and educational missions by protecting and encouraging political and other forms of speech by individual students and student groups" (2017, 48). However, without clear criteria to guide administrators, students will nonetheless be vulnerable to the arbitrary application of ideals such as inclusive freedom. 


\section{So What Is to be Done?}

So what is to be done to ensure the broadest exercise of freedom of expression and associational rights for student political advocacy while at the same time ensuring that their rights to equity free from dignitary harms are upheld? Drawing on the free speech and civil rights movements of the 1960s, Joy James (2018) argues that today a similar response is needed, that is, one that collectively takes responsibility for fighting against the onslaught of hate speech and far-right xenophobia. Alan Sears agrees. He believes the challenge lies in building long term resistance for "militant mass mobilization that can fight to transform colleges and universities from below into the kinds of educational spaces that meet student needs and serve as good places to work" $(2019,5)$. Reflecting on the syndicalist movement of student's and workers' solidarity struggles of the 1960s, Sears asserts that what is needed is mobilizing educational strategies, tabling counterdemonstrations, and building meaningful solidarity with marginalized folks to overturn the extreme right (Sears 2019). I concur.

While I believe it is important to maintain the broadest understanding of expressive freedom on campus, especially for public speakers, given the educational context within which post-secondary institutions operate, it is incumbent upon its members that all students are protected from dignitary harms. I believe that this balance can be achieved through an emphasis on our collective responsibility in ensuring that a group's dignity is not harmed-one that moves away from an individualistic understanding of rights, to one that emphasizes our collective responsibility to others beyond oneself. By adopting principles that protect one's dignity from harm-that is, harm to a group's reputation, their status and good standing in society, and the damage that hate speech may do to it (Waldron 2012, 139)—students will be better able to balance their right to freedom of expression with their fundamental right to learn and participate in the collegium free from the exigencies of discrimination and harmful speech. Moreover, in doing so, administrators will expand the narrow liberal conception of rights and ensure marginalized peoples' voices and worldviews are heard. Such an approach represents a decolo- nial shift and has the potential of expanding what counts as knowledge and truth in todays academy.

\section{Endnotes}

1. I adopt Sami scholar Rauna Kuokkanen's understanding of responsibility that links consciousness with conscience (2008). She states: "It is not enough to merely know one's responsibilities; one must also be aware of the consequences of one's actions. ... This starts by addressing one's privilege...It requires the critical examination of one's beliefs, biases, and assumptions as well as an understanding of how they have developed and become naturalized in the first place" $(2008,115)$.

2. While the Alberta Court of Appeal upheld a students' Charter rights to freedom of expression under Section 2(b) of the Charter in both the UAlberta ProLife v. Governors of the University of Alberta (2020 ABCA 1) and Pridgen v. University of Calgary, (2012 ABCA 139), the Supreme Court of Canada has yet to rule on a student's Charter rights.

3. See Murrell (2017) for firsthand accounts by students in Shepherd's tutorial class that were present when she introduced the TVO clip to the class.

4. Under the Wilfrid Laurier University Act (1973) the President has the right to make unilateral decisions regarding a student's non-academic behaviour (Universities Canada 2018). This said, all universities must comply with the Canadian Criminal Code, including hate speech laws and human rights legislation. In this situation, it would appear that President MacLatchy erred on the side of free speech to avoid conservative media pundits' criticism.

5. Doxing is when an individual's personal information is shared online and may be used to pose a personal threat to the individual. 


\section{References}

Ben-Porath, S. 2017. Free Speech on Campus. Philadelphia: University of Pennsylvania Press.

Ben-Porath, S. December 11, 2018. "What the Chicago Principles miss when it comes to free speech and academic freedom (opinion)." Inside Higher Ed. Retrieved from https:/www.insidehighered.com/views/ 2018/12/11/what-chicago-principles-miss-when-itcomes-free-speech-and-academic-freedom-opinion.

Bill C-16. 2017. An Act to Amend the Canadian Human Rights Act and the Criminal Code. S.C., c.13.

Bird, G. 2017. "Wilfrid Laurier University faculty petition." Change.org. Retrieved from www.change.org/p/greg-bird-wilfrid-laurier-universityfaculty-open-letter.

Blatchford, C. November 10, 2017. "Thought police strike again as Wilfrid Laurier grad student is chastised for showing Jordan Peterson video.” National Post. Retrieved from http://nationalpost.com/opinion/ christie-blatchford-thought-police-strike-again-aswilfrid-laurier-grad-student-is-chastised-for-showingjordan-peterson-video.

Brulé, E. 2015. "Voices from the margins: The regulation of student activism in the new corporate university." Special Issue of Studies in Social Justice, "Scholar-Activist Terrain in Canada and Ireland II," 9 no. 2, 159-75.

Cameron, J. 2014. "Giving and taking offence: Civility, respect, and academic freedom." In Academic Freedom in Conflict: The Struggle Over Free Speech Rights in the University edited by J. Turk, 288-304. Toronto: James Lorimer.

Canadian Association of University Teachers (CAUT). December, 2018. "The politics of free speech."

Toronto: CAUT. Retrieved from https://www.caut.ca/ bulletin/2018/12/politics-free-speech.

Canadian Association of University Teachers (CAUT). April, 2019. Interview, Penny Stewart. Toronto:
CAUT. Retrieved from https://www.caut.ca/bulletin/ 2019/04/interview-penni-stewart.

Canadian Broadcasting Corporation (CBC News). (2019, October 11). "'We'll make you bleed:' Queen's University investigating racist and homophobic note posted inside dorm." Toronto: CBC. Retrieved from https://www.cbc.ca/news/canada/toronto/queensuniversity-chown-note-1.5318580.

Canadian Charter of Rights and Freedoms, Part I of the Constitution Act, 1982, being Schedule B to the Canada Act (UK), c 11.

Canadian Jewish News (CJN). June 10, 2020. "JDL head banned from York University." Canadian Jewish News, 1-3.

Carey, K. 2016. "On cleaning: Student activism in the corporate and imperial university." Open Library of Humanities, 2 no. 2, 1-52. Retrieved from https:// olh.openlibhums.org/articles/10.16995/olh.92/.

Chaudhury, A. November 28, 2017. "The WLU/ Lindsay Shepherd controversy was never about free speech." Medium. Retrieved from https:// medium.com/@thylacinereport/the-wlu-lindsayshepherd-controversy-was-never-about-free-speech9 fe3442da3c3.

Chemerinsky, E., \& Gillman, H. 2017. Free Speech on Campus. New Haven: Yale University Press.

Chiose, S. Oct. 19, 2017. "Dalhousie defends free expression as student faces hearing over Canada 150 post." Globe \& Mail. Retrieved from https:// www.theglobeandmail.com/news/national/dalhousiedefends-free-expression-canada-150/article36679279/.

Cloud, D. 2015. "'Civility' as a threat to academic freedom.” First Amendment Studies, 49 no. 1, 3-17.

Cohn, M. Feb. 15, 2019. "Doug Ford's fearless fight against the Communist threat on Ontario campuses." Toronto Star. Retrieved from www.thestar.com/politics/ political-opinion/2019/02/15/doug-fords-fearlessfight-against-the-communist-threat-on-ontario- 
campuses.html.

Criminal Code of Canada, RSC, 1985, c C - 46 Sec 319(I).

Cromwell, T. April 30, 2020. York University Independent Review. Ottawa: Honourable Thomas A. Cromwell C.C.

Federal Bureau of Investigation. 2001. Terrorism 2000/2001. FBI Publication \#3008, Washington, D.C.: US Department of Justice,

James, J. November 23, 2018. "The (un)fair fight for a just democracy." Feminist Wire, 1-6.

Journal Editorial Board. January 31, 2020. "Panel discussion grapples with hate speech, free speech." The Journal-Queen's University, 1-6.

Koukkanen, R. 2008. Reshaping the University: Responsibility, Indigenous Epistemes, and the Logic of the Gift. Vancouver: UBC Press.

Lam, P. November 29, 2017. "Rancour of free speech debate led gender-diverse people to feel unsafe, advocates say." CBC News. Retrieved from www.cbc.ca/news/canada/kitchener-waterloo/freespeech-unsafe-1.4424489.

Masri, M. 2011. "A tale of two conferences: On power, identity, and academic freedom." AAUP Journal of Academic Freedom 2, 1-28.

Moon, R. 2014. "Demonstration on campus and the case of Israeli Apartheid Week." In Academic Freedom in Conflict: The Struggle Over Free Speech Rights in the University edited by J. Turk, 185-204. Toronto: James Lorimer.

Moon, R. November 21, Fall, 2018. "Understanding the right to freedom of expression and its place on campus." Academic Matters, 1-14.

Murrell, A. Nov. 27, 2017. "The Debate of Free Speech at Wilfred Laurier University." Her Campus at Wilfrid Laurier. Retrieved from https:// www.hercampus.com/school/wilfrid-laurier/debatefree-speech-wilfrid-laurieruniversity? utm_campaign=shareaholic\&utm_medium=facebook \&utm_source=socialnetwork.

Nadeau, M-J., \& Sears, A. March 5, 2011. "This is what complicity looks like: Palestine and the silencing campaign on campus." The Bullet, 475. Retrieved from www.socialistproject.ca/bullet/475.php.

Ontario Human Rights Commission. November 18, 2018. A Collective Impact: Interim Report on the Inquiry into Racial Profiling and Racial Discrimination of Black Persons by the Toronto Police Service. Toronto: Ontario Human Rights Commission, Government of Ontario.

Ontario, Office of the Premier. August 30, 2018. "Upholding free speech on Ontario's university college campuses." News Ontario. Retrieved from https:// news.ontario.ca/opo/en/2018/08/upholding-freespeech-on-ontarios-university-and-collegecampuses.html.

Ontario Human Rights Commission (2018, November 18). A Collective Impact: Interim Report on the Inquiry into Racial Profiling and Racial Discrimination of Black Persons by the Toronto Police Service. Toronto: Ontario Human Rights Commission, Government of Ontario.

Palfrey, J. 2017. Safe Spaces, Brave Spaces: Diversity and Free Speech Expression in Education. Cambridge, MA: MIT Press.

Post, R. 2002. "Constitutionally interpreting the FSM controversy." In The Free Speech Movement: Reflections on Berkeley in the 1960s, edited by R. Cohen \& R. Zelnick, 401-21. Berkeley and Los Angeles: University of California Press.

Pridgen v. University of Calgary. 2012. ABCA 139 (CanLII).

Rahr, M. October 23, 2017. "Dalhousie faculty pen letter in support of Masuma Khan." The Coast. Retrieved from https://www.thecoast.ca/RealityBites/ 
archives/2017/10/23/

dalhousie...al\&utm_campaign=The+Coast, +Halifax\%27s+Weekly\&utm_content=Breaking.

Rangwala, S. August 31, 2019. "The real free-speech crisis on Alberta's campuses might not be what you think it is." Globe \& Mail. Retrieved from https:// www.theglobeandmail.com/opinion/article-the-realfree-speech-crisis-on-albertas-campuses-might-not-bewhat/.

Sachs, J. Sept. 10, 2019. "Canada's new definition of anti-Semitism is a threat to campus free speech." University Affairs. Retrieved from https:// www.universityaffairs.ca/opinion/in-my-opinion/ canadas-new-definition-of-anti-semitism-is-a-threatto-campus-free-speech/.

Schneiderman, D. 2014. "Academic freedom and the federal idea." In Academic Freedom in Conflict: The Struggle Over Free Speech Rights in the University, edited by J. Turk, 218-30. Toronto: James Lorimer.

Sears, A. March 19, 2019. "Fighting Ford on campus: Resisting the Tory agenda for postsecondary education." New Socialist: Ideas for Radical Change. Retrieved from https://newsocialist.org/fighting-fordon-campus-resisting-the-tory-agenda-forpostsecondary-education/.

Smeltzer, S., \& Hearn, A. 2014. "Student rights in an age of austerity? 'Security,' freedom of expression and the neoliberal university." Social Movement Studies: Journal of Social, Cultural and Political Protest, 14 no. 3, 352-58.

Spencer, L., Tyahur, P., \& Jackson, J. 2016. "Civility and academic freedom: Extending the conversation." Journal of Contemporary Rhetoric, 6 no. 3-4, 50-61.

Stewart, P. 2010. "Academic freedom in these times: Three lessons from York University." Cultural and Pedagogical Inquiry, 2 no. 2, 48-61.

Svonkin, C. October 18, 2019. “'We're going to let this strengthen us:' Students of Chown Hall floor speak to racist note." Queen's University Journal.
Retrieved from https://www.queensjournal.ca/story/ 2019-10-18/news/were-going-to-let-this-strengthenus-students-of-chown-hall-floor-speak-to-racist-note/.

Turk, J. 2014. "Introduction." In Academic Freedom in Conflict: The Struggle Over Free Speech Rights in the University, edited by J. Turk, 11-20. Toronto: James Lorimer.

Turk, J. 2017. "The landscape of the contemporary university." Canadian Journal of Communication, 42 no. 1, 3-12.

Turk, J., \& Manson, A. (eds.). 2017. Free Speech in Fearful Times: After 9/11 in Canada, the U.S., Australia and Europe. Toronto: James Lorimer.

UAlberta Pro-Life v. Governors of the University of Alberta. 2020. ABCA 1 (CanLII).

Universities Canada. October 25, 2011. "Association of Universities and Colleges of Canada (AUCC) statement of academic freedom." Retrieved from www.univcan.ca/media-room/media-releases/ statement-on-academic-freedom/.

Universities Canada. 2018. "Universities/facts and stats/enrolment by university." Retrieved from www.univcan.ca/universities/facts-and-stats/ enrolment-by-university/.

University of Western Ontario. "University of Western Ontario's Code of Conduct 1.9." Retrieved from www.uwo.ca/univsec/board/code.pdf.

Waldron, J. 2012. The Harm in Hate Speech. Cambridge, MA: Harvard University Press.

York University, Office of the President. December 10, 2019a. "An update to the York community from Sheila Cote-Meek and Lucy Fromowitz." Retrieved from https://president.yorku.ca/strategicpriorities/ campus-dialogue/community-update_dec10/.

York University, Office of the President. 2019b. "Independent external review of Nov. 20, 2019 incident." Retrieved from https://president.yorku.ca/ 
strategicpriorities/campus-dialogue/independentexternal-review/.

Zachariah, C. January 28, 2019. "Why is Doug Ford so afraid of student unions?" The Blog. HuffPost Canada. Retrieved from www.huffingtonpost.ca/ canadian-federation-of-students/doug-ford-studentunions_a_23652711/.

Zhou, S. Spring, 2017. "Canada's university administrators must pay attention to right-wing activism on campuses." Academic Matters. Retrieved from https://academicmatters.ca/canadas-universityadministrators-must-pay-attention-to-right-wingactivism-on-campuses/. 